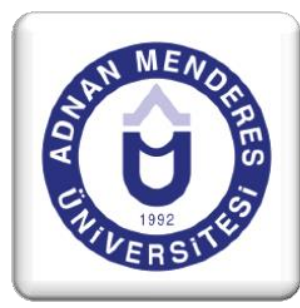

\title{
Merkez Bankasının Bağımsızlığı, Yönetişim, Enflasyon ve Ekonomik Büyüme
}

\section{The Central Bank Independence, Governance, Inflation and Economic Growth}

Aslı Yenipazarl $1^{1}$

\section{Özet}

Bu çalışma merkez bankasının bağımsızlığı konusunu ekonomik ve politik bağlamda açıklamaya çalışmaktadır. Bağımsızlık kavramı teorik çerçevede ortaya konmuş, yönetişim kavramı ile ilişkilendirilmeye çalışılmıştır. Literatürde bu konuda yapılan çalışmalar değerlendirilmiş, özetlenmiştir. Yasal bağımsızlık endeksi değerlerinin Türkiye Cumhuriyet Merkez Bankası'na ait verilerde, enflasyon ve ekonomik büyüme ile ilişkisi gösterilmişsir. Merkez bankası bağımsızlı̆ının makroekonomik performansa etkisi belirtilmiştir.

Anahtar Kelimeler: Merkez Bankasının Bağımsızlığı, Türkiye Cumhuriyet Merkez Bankası, Yönetişim, Enflasyon, Ekonomik Büyüme.

\section{Abstract}

In this study, central bank independence is tried to be explained economically and politically. The term independence is theoretically introduced. The relation between central bank independence and governance is brought up according to the literature. The legal independence values for Central Bank of Republic of Turkey are related with inflation and economic growth. So the effects of independence on macroeconomic performance are explained.

Keywords: Central Bank Independence, Central Bank of Republic of Turkey, Governance, Inflation, Economic Growth.

\footnotetext{
${ }^{1}$ Yrd. Doç. Dr., Adnan Menderes Üniversitesi, Nazilli İ̈BF, İktisat Bölümü, ayenipazarli@adu.edu.tr
} 


\section{GíRiş}

Merkez bankasının bağımsızlı̆̆ı literatüre göre, enflasyonu düşürmekte yardımcı olabilecek bir kurumsal özelliktir. Tüm dünyada yüksek enflasyonun ekonomiye ve topluma zarar verdiği ve fiyat istikrarının; ekonomik istikrarın, sürdürülebilir büyüme ve istihdam artışının olmazsa olmaz bir önkoşulu olduğu kabul edilmektedir. Merkez bankalarının bağımsızlığı modern ekonomilerde, özellikle 1990'lı yılların başından itibaren, fiyat istikrarı sağlamanın önkoşulu olarak görülmektedir.

Merkez bankası yasalarla kurulduğundan, merkez bankası ve hükümet arasında her zaman bir iliş̧ki vardır. Aslında, bu iki olguyu tamamen birbirinden ayırmak mümkün değildir. Bu bağlamda merkez bankalarının bağımsızlığı ve yönetişim kavramları arasında sıkı bir ilişki vardır.

Araştırmacılar, merkez bankasının bağımsızlığı ve yönetişim kavramları ile ilgili farklı endeksler ve ölçüm araçları geliştirmişlerdir. Bazısı, ekonomik bağımsızlık gibi para politikasına, ya da hesap verebilirlik ve şeffaflık konularına işaret etmektedir. Merkez bankası bağımsızlığı ve yönetişim konuları tartışmalı olduğundan, yasal, siyasal, ekonomik ve diğer bağımsızlık konuları içlerinde farklı görüşler barındırmaktadır. Bir yazarın, yasal bağımsızlık olarak tanımladığı kavram, başkasına göre siyasal (politik), ekonomik ya da politika bağımsızlı̆̆ olabilmektedir.

Bu çalışma kapsamında merkez bankası bağımsızlığı ekonomik ve politik bağlamda yönetişim konusu ile ilişkilendirilmektedir. Merkez bankasının bağımsızlığı konusu teorik olarak ortaya konduktan sonra, yönetişim ve merkez bankası bağımsızlığı ilişkilendirilmiş, son olarak da enflasyon ve ekonomik büyüme üzerinde bağımsız bir merkez bankasının etkisi ortaya konmuştur.

\section{MATERYAL VE YÖNTEM}

Çalışma kapsamında, merkez bankasının bağımsızlığı, yönetişim, enflasyon, ekonomik büyüme gibi kavramlar mevcut literatürün taranması yöntemi ile incelenmiştir. Literatürdeki güncel araştırmalar, teorik ve ampirik bulgularıla incelenmiş, Türkiye Cumhuriyet Merkez Bankası (TCMB)'na ait yasal bağımsızlık, son döneme ilişkin enflasyon ve ekonomik büyüme rakamları ile ilişkilendirilmiştir. İncelenen değişkenler, sayısal verileriyle 1980 sonrasını gösterir biçimde analiz edilmiştir.

\section{MERKEZ BANKASININ BAĞIMSIZLIĞI}

Ekonomi politikalarının temel amacı toplumsal refahı artırmaktır. Toplumsal refahın artırılması ise temel olarak sürdürülebilir büyümenin sağlanmasına dayanmaktadır. Merkez bankalarının sürdürülebilir büyüme ve refahın artırılmasına yönelik en temel katkısının fiyat istikrarının sağlanması ve sürdürülmesi yoluyla olduğu, üzerinde fikir birliği sağlanan bir görüştür. Yüksek enflasyon toplumsal refahı olumsuz etkilemekte; fiyat istikrarı ise ekonomik istikrarın, diğer bir deyişle sürdürülebilir büyüme ve istihdam artışının ön koşulu olarak kabul edilmektedir. Fiyat istikrarının sağlanması ve sürdürülmesi uzun vadeli bir bakış açısıyla oluşturulan politikaların uygulanmasını gerektirmektedir. Öte yandan, dışsal şokların yanı sıra, politika uygulayıcıların ekonomiyi kapasitesinin üzerinde çalıştırma istekleri veya yüksek kamu borçlarını merkez bankası kaynakları ile finanse etme eğilimleri, fiyat istikrarını tehdit eden unsurlar arasındadır. Bu noktada merkez bankalarının fiyat istikrarına karşı tehdit olabilecek risklere karşı durabilmeleri ve gerekli uyarıları yapabilmeleri merkez bankası bağımsızlığının temelini oluşturmaktadır (www.tcmb.gov.tr).

Merkez bankasının bağımsızlığına ilişkin olarak birbirine benzeyen birçok ayrım yapılmıştır. Merkez bankasının bağımsızlı̆̆ını birbiri ile ilişkili üç temel yapı içinde düşünmek mümkündür. Bunlardan ilki mülkiyet bağımsızlığıdır. Bankanın sermayesinin devlete ait olmaması halinde mülkiyet bağımsızlığından bahsedilebilir. İkincisi personel açısından bağımsızlıktır. Merkez bankasının yöneticilerinin seçilmesi ve görevlerinden ayrılması konusunda hükümetin hiçbir yetkisi yoksa personel açısından bağımsızlık söz konusudur. Üçüncü olarak fonksiyonel bağımsızlık ise 
merkez bankasının para politikasının belirlenmesi konusunda hükümete bağlı olmamasını ifade eder (Dileyici ve Özkıvrak, 2000: 1).

Para politikasının oluşturulması için merkez bankalarının bağımsılığıııı arttırma konusuna büyük ilgi bulunmaktadır. Örneğin Şili ve Yeni Zelanda 1989 'da yürürlüğe giren yeni bir yasa kabul etmiştir. Ayrıca sanayileşmiş pek çok ülkede de merkez bankasının özerkliğinin arttırılması konusunda bazı müzakereler yapılmaktadır. Özellikle Avrupa Para Sistemi'nin üyesi olan bazı ülkelerin görüşleri doğrultusunda şekillenen Avrupa Para Birliği'nde, bağımsız ulusal merkez bankalarından daha önce ülkeler üstü bağımsız bir merkez bankacılığı sistemine bağlı olan gereksinimi ortaya çıkarmıştır.

Bütün bu gelişmeler doğal olarak merkez bankaları ile hükümetler arasında istenilen ilişki hakkında önemli tartışmaları ortaya çıkarmıştır. Siyaset bilimciler ve ekonomistler genellikle, merkez bankası bağımsızlığının enflasyonu düşürdüğü konusunda hemfikirdirler. Her iki grup da, merkez bankası bağımsızlığını bir merkez bankasının para politikasını uygularken siyasi otoritelere karşı özerk olma derecesi olarak tanımlamaktadır.

Demokratik toplumlarda yürütülen makroekonomi politikası ile politik yapı arasında sıkı bir ilişki vardır. Bu ilişki nedeniyle, genelde makro ekonomik politika ve özelde parasal politika, politik süreç tarafindan kolayca etkilenebilir ve politik çıkarlar doğrultusunda yönlendirilebilir (Oktar, 1996: 68).

Politikacı için politika yapmanın amacı iktidar olmak ve bunu uzun süre korumaktır. Buna karşılık, uygulanan makro ekonomik politika, bu amaca ulaşmanın bir aracıdır. Burada araç ve amaç ilişkisi ayrılmaz bir biçimde birliktelik gösterir. Bu ilişki öylesine güçlüdür ki, politik seçimler ekonomik koşulların sonucu olarak kazanılır ya da kaybedilir (Alesina, 1989: 57).

Merkez bankasının para politikası özerkliği, bir derece problemlidir. Siyasi otoriteden tamamen bağımsızlık sağlanamaz. Çünkü bankanın politikaları sonucunda istenmeyen durumlar ortaya çıkmışsa, siyasi otorite yasal ve anayasal değiş̧iklikler yapabilir. Fakat bağımsızlık hiç yoktur anlamina gelemez.

Para politikasını yönetmek ve izlemek politik ve ekonomik olarak maliyetli bir iştir. Çünkü bankalar hükümetlere, uzmanlık ve enformasyon alanında üstünlük taslamaktan hoşlanırlar ve hükümetlerin bankaları denetlemesi için zaman ve diğer kaynaklara ihtiyaç vardır. Bundan dolayı, hükümetler merkez bankalarının politika uygulamalarını, istediği gibi denetleyemez. Dolayısıyla, merkez bankası bağımsızlığı, bankanın iktidardaki hükümetin isteklerinden ne kadar uzak olduğuna işaret eder. Böylece, para politikası ve enflasyon hem merkez bankası ve hem de hükümet tarafindan kontrol edilir.

Merkez bankasının araç bağımsızlığı olması gerektiği fakat amaç bağımsızlığı olmaması gerektiği yaygın bir kanıdır. Bunun da iki sebebi vardır: (i)Ulusun parasal amacı ulusun sosyal refah fonksiyonunu yansıtır, sadece merkez bankası yöneticisinin tercihlerini değil, (ii) Maliye ve para politikalarının her ikisinde de karşılıklı amaçlarının çakışmasının önlenmesi için para ve maliye politikalarının düzenlenmesi gereklidir

Merkez bankası hesap verebilirliği, ulusun parasal amaçlarının merkez bankası tarafından izlenmesi gerektiği için lüzumludur. Yeni Zelanda'da, merkez bankası yöneticisi maliye bakanına karşı sorumludur. ABD'de FED (ABD Merkez bankası) kongreye karşı sorumludur. Kongre de FED Başkanını seçer ve politikalarını açıklamak üzere atar. Almanya'da Bundesbank, paranın değerinin korunması için gerekli politikaları uygulamakla sorumludur. Avrupa'da merkez bankaları içerisinde bağımsızlıkla ilgili kıstaslar dikkate alındığında Almanya Merkez Bankası en bağımsız merkez bankasıdır. Kanundan gelen bağımsızlık yönünden birinci, merkez bankası başkanının değişim süresi yönünden dokuzuncu sırada yer alan ve ekonomik, politik kurumlardan bağımsız olarak çalışan Bundesbank, Alman toplumunun desteğine ve tam güvenine sahip bulunmaktadır (Afşar, B., 2006: 2)

Şeffaflık ve sorumluluk da hükümetin para politikasında güvenilirliğin sağlanması için çok önemlidir. Bir merkez bankası ne kadar çok güvenilir ise, yüksek enflasyonist beklentilere yol açmadan ve daha yüksek uzun dönem faiz oranları ya da faiz oranlarının yükseltilmesi, bir durgunluk korkusu olmaksızın enflasyonist baskıları yenebilir, böylece faiz oranlarını düşürmede daha başarılı olacaktır. Bu da şeffaflık ve hesap verebilirliği, güvenilirliği ve etkinliği arttırmakla olur. 
Birçok çalışmada, merkez bankasının bağımsızlığı için dört kriter belirlenmiştir: (i) Merkez bankası başkanı ve üyelerinin değişme sıklığı, (ii) Para politikasının belirlenmesi kıstasları, (iii) Merkez bankasının amaç veya amaçlarının belirlenmesi kıstasları, (iv) Kamu kesimine açılan kredilerin sınırları ile ilgili kıstaslar (Grilli, Masciandaro, Tabellini, 1991; Alesina ve Summers, 1993; Cukierman, 1994).

Birincide; merkez bankalarının görevde kalış süresinin uzunluğu ve kısalığı, görevine kimin son verdiği önem taşımaktadır. Merkez bankası üyeleri hiçbir baskıya maruz kalmadan uzun dönem yani hükümet ile ortaya çıkan görüş ayrılığı durumunda merkez bankasının durumunu güçlendiren yasal düzenlemelerin varlığında görevlerinde kalabiliyorlarsa bağımsız kabul edilmektedir.

İkincisi; para politikası belirlenirken merkez bankası ve hükümet arasında oluşabilecek sorunlarda kimin daha etkili olduğu ve merkez bankasının rolünün ne olduğuna bakılmakta ve merkez bankası gerek bütçede gerekse diğer kaynaklarda aktif rol alıyorsa bağımsız kabul edilmektedir.

Üçüncüsü; merkez bankasına fiyat istikrarı dışında başka amaçlar yüklenmiyorsa bağımsız, ancak diğer hedefler (tam istihdam, ekonomik büyüme) de yüklendiğinde bağımsızlık azalıyor demektir.

Son olarak, merkez bankası kamu kesimine kredi açmıor veya fazla kamu finansmanında yer almıyorsa bağımsız kabul ediliyor. Kamu kesimi açıklarının büyük boyutlara ulaşması ve bu açıkları kapatmak için başvurulan yol çok önemlidir. Kamu açıkları vergi gelirleriyle kapatılmayıp, hazine ve diğer kamu kurumları merkez bankasından borçlanma yoluna giderse bu durum para politikasının etkinliğini azaltacaktır. Çünkü merkez bankası bu açıkları kapatmak için emisyonu artıracaktır. Böylece para arzı genişleyecektir. Ayrıca merkez bankasının hazineye verdiği kredilerin artması bankacılık kesimine vereceği kredileri daraltacaktır. Dolayısıyla merkez bankasının bankacılık kesimi üzerinde denetimi azalacaktır.

Bir ekonomide, kamusal alanda para akımını yürüten birden fazla kurum mevcut ise para otoritesi konumundaki merkez bankasının karşısındaki kurumlar arasında uyum sağlaması gerekir. Bu uyum yoksa yapılan açıklamalar çelişkili ve tutarsız olur. Sonuçta bu durum merkez bankasının uygulayacağı para politikasının etkinliğini azaltacaktır.

\subsection{Politik Bağımsızlık}

Politik bağımsızlık, merkez bankasının hedeflerini hükümetin siyasi tercihleri ve baskısı olmadan belirleyebilmesidir. Yani iktisat politikasının amaçları çerçevesinde merkez bankasının para politikasını başka bir kurumdan talimat almadan yürütmesidir (Kılıç, 2002).

Politik açıdan bağımsız bir merkez bankası için arzu edilen durum başkan ve yönetim kurulu üyelerinin hükümet tarafından atanmamasıdır. Atamalarla ilgili başka bir konu da, başkan ve yönetim kurulu üyelerinin görevde kalma süreleridir. Merkez Bankasının politik bağımsızlığı yüksek olmayan ülkelerde ortaya çıkan en önemli sorun, başkan ve yönetim kurulu üyelerinin sık sık değişen hükümetlerle beraber değişmesidir. Politik bağımsızlıktan söz edebilmek için başkan ve yönetim kurulu üyelerinin beş yıldan daha uzun bir süre için atanmaları gerekmektedir.

Merkez bankasının hükümetle olan ilişkilerinin derecesini ölçen iki kriter bulunmaktadır. İlk kritere göre banka yönetim kurulunda hiç hükümet temsilcisi bulunmamalı. İkinci kritere göre de, para politikasının belirlenmesinde merkez bankası bağımsız hareket edebilmeli ve hükümet müdahalesi bulunmamalıdır (Grilli ve diğerleri, 1994).

Politik bağımsızlığın diğer göstergelerinden biri de, bankanın kurumsal düzenlemeleriyle ilgilidir. Hükümetle ortaya çıkan sorunlarda bankanın hükümet karşısında haklarını savunan yasal düzenlemelerin bulunması gerekir.

\subsection{Ekonomik Bağımsızlık}

Merkez bankasının para politikası araçlarına sınırlama getirilmeden kullanılabilmesidir. Ekonomik bağımsızlığın en önemli ölçütü, merkez bankasıyla siyasi otorite arasındaki finansal 
ilişkidir. Burada kastedilen kamu harcamalarının merkez bankası kredileri ile finanse etmede hükümete sağlanan olanaklardır. Bu olanakların az olması merkez bankasının bağımsızlığını arttırıcı bir rol oynar.

Tablo 1: Ekonomik Bağımsızlık Göstergeleri

\begin{tabular}{|c|c|}
\hline $\begin{array}{c}\text { Temel } \\
\text { Gruplar }\end{array}$ & Kriterler \\
\hline $\begin{array}{l}\text { Bütçe } \\
\text { açıklarının } \\
\text { parasal } \\
\text { finansmanı }\end{array}$ & $\begin{array}{l}\text { (1) Otomatik olmayan direkt kredi kolaylı̆̆ } \\
\text { (2) Piyasa faiz oranı üzerinden verilen direkt kredi } \\
\text { (3) Geçici olarak verilen direkt kredi kolaylığı } \\
\text { (4) Sınırlı miktarda verilen direkt kredi } \\
\text { (5) Merkez bankası, kamu kurumlarının borç senetlerini almak için birincil } \\
\text { piyasaya girmez. }\end{array}$ \\
\hline $\begin{array}{l}\text { Parasal } \\
\text { açıklar }\end{array}$ & $\begin{array}{l}\text { (1)Iskonto oranı merkez bankası tarafından belirlenir } \\
\text { (2)Bankanın finansal yönetiminden merkez bankası sorumlu değildir ya da } \\
\text { bankanın yönetiminden merkez bankası tek başına sorumlu değildir. }\end{array}$ \\
\hline
\end{tabular}

Kaynak: Grilli vd. (1994)

Ekonomik bağımsızlığın ölçülmesinde kullanılan birinci grupta yer alan kriterler, merkez bankasının bütçe açıklarını ne ölçüde finanse ettiğini belirlemek için geliştirilmiştir. Bilindiği gibi bütçe açıklarını otomatik olarak hiçbir sınırlama olmaksızın finanse eden bir merkez bankası tam anlamıyla bağımsız olarak kabul edilmemektedir.

Direkt kredi kolaylığının otomatik olmaması, merkez bankasının ekonomik bağımsızlı̆̆ını arttıran bir unsurdur. Merkez bankası kredileri geçici olarak veriliyorsa merkez bankasının bağımsızlık derecesi yükselmektedir. Ayrıca merkez bankasının vereceği kredi miktarı sınırlandırılmışsa bağımsızlık derecesi yükselmektedir. Merkez bankası başta hazine olmak üzere kamu kurumlarının borç senetlerini almak için birinci piyasaya girmiyorsa, merkez bankasının ekonomik bağımsızlık derecesi yüksek olacaktır (Kılıç, 2002).

\subsection{Yasal ve Gerçek (Fiili) Bağımsızlık}

Merkez bankasının yasal bağımsızlığı, merkez bankası kanunu ile bankaya tanınan bağımsızlığı ifade etmektedir. Gerçek bağımsızlık, banka ile hükümet ve diğer kamu kurumları arasındaki gayri resmi düzenlemeler ve uygulamalardan oluşmaktadır.

Cukierman (1995), gerçek bağımsızlı̆̆ı ölçmek için geliştirilen göstergelerin şu iki nedenle yasal bağımsızlığı tamamlayacağını iddia etmiştir. Birincisi, merkez bankası kanununda boşluk bulunan hallerde, gayri resmi uygulamalar ve geleneklerden yararlanılır. İkincisi de, merkez bankası kanunun açı olduğu hallerde bile gerçek uygulama farklı olabilir.

Ayrıca, merkez bankası bağımsızlığının resmi olarak tanınması için nihaî hedef olan fiyat istikrarının sağlanmasından sorumlu tek otorite olarak yasal bir görevlendirmenin yapılmış olması gerekmektedir (Kılıç, 2002). 


\subsection{Bütçesel Bağımsızlık}

Para politikasının bağımsızlığının derecesi ne olursa olsun, merkez bankaları finansal açıdan genelde hükümetten bağımsız önemli bir serbestliğe sahiptirler. Merkez bankaları özellikle gider bütçelerini çoğunlukla kendileri hazırlayabilmektedirler. Bunun istisnaları Fransa, Japonya, Yeni Zelanda Merkez Bankalarıdır. Politika bağımsızlığına sahip bir banka için muhtemel endişe, bütçesel bağımsızlığın olmadığı bir durumda hükümetler dolaylı bir biçimde bankanın kaynaklarını kullanma hakkını kısıtlayarak bankanın politikası üzerinde yersiz etkilerde bulunabilmesidir. Yeni Zelanda'da hükümetle müzakere edilen ve yıllık bütçe onaylanmasını gerektiren uygulamadan daha ziyade beş yıllık bir dönemi kapsayan finansman anlaşmasıyla merkez bankasının bütçesel bağımsızlığına ilişkin endişe giderilmiştir. Merkez bankasının aleni olarak hükümetin para politikasını uygulaması durumunda, finansal bağımsızlık için hiçbir zorunlu politika tartışması bulunmamaktadır (Castello ve Swisburne, 1992).

Para politikasının bağımsız olarak uygulanmasında kurumsal, işlevsel ve bireysel bağımsızlık kadar merkez bankasının ekonomik olarak da bağımsız olması önem taşımaktadır. Hükümet yetkililerinin merkez bankası bütçesinin ayarlanması ya da merkez bankası finansal araçlarının kullanılması konusunda söz sahibi olması merkez bankası bağımsızlığını ihlal edecektir. Bu amaçla Avrupa Birliği $(\mathrm{AB})$ üyesi ülkelerin merkez bankaları statüleri ve ilgili mevzuatında üçüncü şahısların müdahalesi olarak kabul edilecek bu tür uygulamaları koruyucu yönde hükümlerin kaldırılması ve merkez bankalarının amaçları ve bunları gerçekleştirirken kullanacağı finansal araçların neler olduğunun hiç bir tartışmaya yol açmayacak şekilde tanımlanması uygun görülmüştür.

T.C. Merkez Bankası statüsünde, merkez bankasının bütçesinin oluşturulması ya da kârının dağıtılmasının belirlenmesi konusunda hükümete yasal bir yetki verilmemiş̧ir. Bu yönüyle T.C. Merkez Bankası'nın bağımsızlığı yasayla korunmuştur.

TCMB, enflasyon hedeflemesi rejimine geçilmesiyle beraber, para politikasının temel iletişim aracı olarak Enflasyon Raporu yayımlamaya başlamıştır. Üç ayda bir yayımlanan Enflasyon Raporu'nda enflasyon ve genel makroekonomik gelişmeler kapsamlı olarak ele alınmakta ve TCMB, enflasyona ilişkin öngörülerini ve önceki öngörülerindeki değişiklileri Rapor aracılığıyla kamuoyu ile paylaşmaktadır. Benzer şekilde, TCMB destekleyici amacı olan finansal istikrar doğrultusunda finansal sisteminin bütününe ilişkin görüşlerini, yine şeffaflık gereğince, yılda iki kez yayımlamakta olduğu Finansal İstikrar Raporu ile duyurmaktadır. TCMB günümüzde, kanun ile temel amacı olarak belirlenmiş olan fiyat istikrarını ve destekleyici amacı olan finansal istikrarı sağlamak üzere sahip olduğu araç bağımsızlığı doğrultusunda uygulamalarını sürdürmektedir. Merkez bankasının bir anonim şirket olarak kurulmuş olması ve uygulayacağı para politikası ile kullanacağı para politikası araçlarını doğrudan kendisinin belirlemeye yetkili kılınması, merkez bankası bağımsızlığını garanti altına alan en önemli unsurlardır. Nitekim Avrupa Merkez Bankası'nın bir merkez bankası kanununun bağımsızlık açısından değerlendirilmesinde kullandığı ölçütlere göre, TCMB'nin ilke düzeyinde kurumsal, işlevsel, bireysel ve mali açıdan bağımsız olduğu görülmektedir (TCMB, 2012).

\section{MERKEZ BANKASININ BAĞIMSIZLIĞI VE YÖNETISŞİM}

Merkez bankasının bağımsızlığı ve yönetişim, merkez bankası ile ilişkili iki temel kavramdır. Bağımsızlık, merkez bankasının parasal kontrol mekanizması araçlarını herhangi bir hükümet müdahalesi olmaksızın kullanabilme yetisidir (Henning, 1994). Yönetişim kavramı, otorite, eğilim ve kontrol alıştırmaları ile eşanlamlıdır (Zingales, 1997). Otorite (politikaları yönetebilecek otorite); ekonomiyi amaçlar doğrultusunda yönlendirebilen eğilim ya da yönelim ve hedefe ulaşmak için araçları ve teknikleri kontrol kavramları bir merkez bankası için olası uygulamalardandır. Dünya Bankası yönetişim ilgili şu tanımlamayı yapmaktadır: "Yönetişim, bir ülkenin ekonomik ve sosyal kaynaklarının gelişme amacıyla yönetimde yetkinin kullanılma tarzıdır" (The World Bank 1994). Bunula birlikte, "hesap verebilirlik", "meşruiyetin sağlanması", "yönetimde saydamlı" ve "katılımcılık" gibi kavramlar da yönetişimin kurucu kavramları arasına katılmaktadır (The World Bank, 1992). 
Dünya Bankası'na göre iyi yönetişim, açı ve öngörülebilir bir karar alma sürecinin, profesyonel bir bürokratik yönetimin, eylem ve işlemlerinden sorumlu bir hükümetin, kamusal sürece aktif bir şekilde katılımda bulunan sivil toplumun ve hukukun üstünlügünün geçerli olduğu bir düzeni ifade etmektedir (Karakuş, 2010).

Önceleri, merkez bankası literatürü daha çok bağımsızlık üzerine odaklanmış iken, son zamanlarda literatür daha çok merkez bankası ve yönetişim kavramı üzerine yönelmektedir. Çünkü bu kavram özerklik derecesinin analizini, yöneticiler ve fonksiyonlarını, banka kurulunu ve yönetimini içermektedir. Ayrıca merkez bankasında yönetişim, para politikasının güvenilirliği ve merkez bankası yasasının uygun bir yeniden yapılandırma şekli (reform) anlamına da gelmektedir (Lybek, 2004).

Ayrıca, Amtenbrick (2004)'e göre, merkez bankası ve yönetişimin üç temel unsuru: (i) bağımsızlık, (ii) hesap verebilirlik ve (iii) şeffaflıktır. Bu da demek oluyor ki, iyi yönetişi̇m bir merkez bankasının bağımsızlığının bir fonksiyonudur.

Ahsan, Skully ve Wickramanayake (2006: 59)'a göre merkez bankasının bağımsızlığı ve yönetişim konusunda altı temel belirleyici unsur açıklanmıştır. Değişkenlerin seçimi Şekil 1'de gösterilmiştir. Böylece etkin bir model geliştirilebilir ve her endekse ait politika uygulamaları belirlenebilir.

\section{Şekil 1: Merkez Bankası Bağımsızlık Modeli}

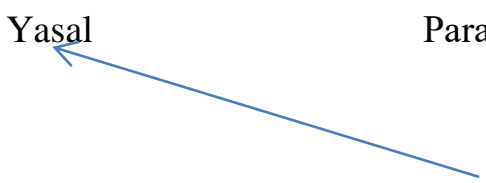

Politik
Para Politikası ve Açık Finansmanı
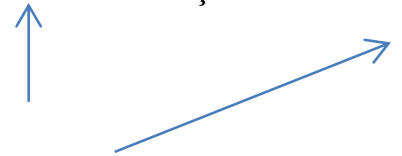

$\mathrm{CBIG}^{2}$
Fiyat İstikrarı Hedefi

Döviz Kuru Politikası

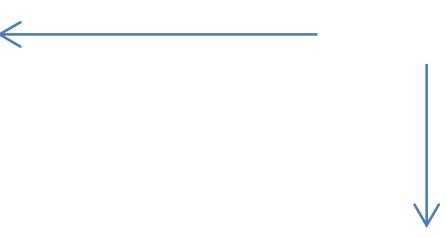

Hesap Verebilirlik ve Şeffaflık

Kaynak: Ahsan, Skully \& Wickramanayake, 2006: 59

Yasal bağımsızlık ölçümü, hükümetin koyduğu yasa ve kanunlarla yapılır. Yasada belirtilen yönetici ile ilgili maddeleri ölçer, bahsedilen madde ile yönetici atanabilir, işten çıkarılabilir, ayrıca merkez bankasının düzenleme sorumluluğu bundan ayrıdır ya da değildir. Düzenleme sorumluluğu ayrılmışsa, bu durumda merkez bankası tüm bankacılık sektörünü yönlendirmek yerine kendi hedeflerini gerçekleştirmek üzere daha fazla zaman ayırma şansına sahip demektir.

Politik bağımsızlık kapsamında ise; yöneticilerin politik ya da apolitik devir hızları, hükümet temsilcisinin banka kurulundaki katılım oranı ve aynı zamanda yöneticinin hükümetin bir kademesinde görev alıp almadığıdır. Eğer yönetici, yeni seçimlerden sonra altı ay içerisinde değişirse, "bu devir politiktir" demektir. Eğer bu değişiklik başka bir nedenden ise, apolitik devir demektir.

Merkez bankasının en önemli ve gerçekleștirmesi beklenen hedefi fiyat istikrarıdır. Merkez bankası bununla birlikte başka hedeflere sahipse ana hedefinden sapma olasılığı vardır. Faiz oranı gibi

\footnotetext{
${ }^{2}$ Central Bank Independence, Governance (Merkez Bankasının Bağımsızlığı ve Yönetişim)
} 
ara hedefi, aynı zamanda da enflasyon hedeflemesi olan merkez bankaları, fiyat istikrarını sağlama temel amacindan sapma gösterebilirler.

Merkez bankasının rolü, sabit, ayarlanabilir ya da dalgalı döviz kuruna uyum sürecine göre değiş̧ebilir. Döviz kuru rejimine kimin karar verdiği, döviz kuruna müdahale, döviz kuru kontrolü ve döviz kuru ile borçlanma konuları da merkez bankasının rolü kapsamında ele alınabilecek diğer konular arasinda yer almaktadır.

Merkez bankasının para politikası ve açık finansmanı bağımsızlığı şu şekilde belirlenebilir: Para politikasının oluşturulmasında sorumlu otorite incelenerek, çatışmanın çözülmesinde son söz, hükümete borç verme, maddeleri ve koşulları belirlenir. Esnek vade ve düşük faiz oranı her zaman merkez bankasının finansal açıdan etkinliğini azaltır.

Merkez bankaları bağımsız oldukları kadar şeffaf da olmalıdırlar. Politikaların tasarım ve uygulama çerçevesinde merkez bankaları toplumla daha fazla bilgi paylaşmalı ve etkin bir iletişim politikası yürütmelidir. Merkez Bankalarının bağımsız olmaları demek toplumun gözü önünde olmaları demektir. Şeffaflığın arttırılması ve etkin iletişim ekonomiye ve para politikasına en önemli katkısı geleceğe ilişkin belirsizliği azaltmasıdır. Merkez bankalarının şeffaf olmaları ve ayrıca iletişime önem vermeleri para politikalarının öngörülebilirliğini arttırmaktadır. Şeffaf bir merkez bankasının hedefleri her zaman açık ve basit (anlaşılabilir) olmalıdır. Merkez bankası önceliklerini belirler ve halkla iletişime geçer. Ekonomik ve diğer ilgili verilerin rapor edilmesi ekonomideki diğer paydaşların merkez bankası faaliyetlerine güvenini artırır. Bir merkez bankası hesap verebilir olabilir fakat bu durum hükümete değil, parlamentoya olmalıdır, yoksa hükümetin diktatörlüğü hissedilebilir.

\section{MERKEZ BANKASININ BAĞIMSIZLIĞI ve MAKROEKONOMIK PERFORMANS}

Merkez bankasının bağımsızlı̆̆ı ve enflasyon ilişkisi, ayıca merkez bankasının bağımsızlığının ekonomik büyüme üzerine etkisinin ortaya konması, para politikası ve makroekonomik performansa yönelik bir fikir vermektedir. Öncelikle, merkez bankasının bağımsızlığının enflasyon ve ekonomik büyüme üzerine etkisini araştıran çalışmalar incelenmiş ve sonuçları değerlendirilmiştir.

\subsection{Merkez Bankasının Bağımsızlığı, Enflasyon ve Ekonomik Büyüme İlişkisi Üzerine Çalışmalar}

Merkez bankasının bağımsızlığı ve enflasyon konusunda literatürde yer alan çalışmalar incelendiğinde, Cukierman, Webb, Neyaptı (1992), merkez bankalarının fiyat istikrarını sağlayacak bir kurum haline gelmesinin hükümetlerin de fiyat istikrarını sağlamadaki kararlılığını gösterdiğini ortaya koymuştur. Çalışmada, merkez bankasının bağımsızlığı dört kategoride ölçülmüş, bu kategorilerin enflasyonla ilişkisi incelenmiştir. Ölçümler sonucunda 72 ülke için yasal bağımsızlık endeksi oluşturulmuş, sanayileşmiş ülkeler için bağımsızlık enflasyon ilişkisi negatif bulunmuştur. Enflasyonun kontrol altına alınmasındaki başarı merkez bankalarının bağımsız olmalarını sağlamaktır.

Haan ve Kooi (2000), merkez bankası bağımsızlığı ve enflasyon ilişkisini 82 gelişmekte olan ülkeyi kapsayacak şekilde incelemiştir. Bu çalışmada, merkez bankasının bağımsızlığı, enflasyon, bütçe açıkları ve ekonomik büyüme arasında ilişki olup olmadığı araştırılmıştır. Merkez bankasının bağımsızlığı ve enflasyon ilişkisi yüksek enflasyona sahip ülkeler için daha belirgin bulunmuş, bütçe açıkları ve ekonomik büyümenin merkez bankasının bağımsızlığı ile ilişkisi bulunamamıştır.

Sturm ve Haan (2001) çalışmasında merkez bankasının bağımsızlı̆̆ının enflasyon ilişkisi gelişmekte olan ülkelerde analiz edilmiştir. Bu çalışmada da yüksek enflasyona sahip ülkelerde korelasyonun daha yüksek olduğu tespit edilmiştir.

Borrero (2001) çalışmasına göre ise, merkez bankasının bağımsızlı̆̆ının yüksek olması mali disiplini artırmakta, enflasyon ve büyümenin düşmesine neden olmaktadır. Enflasyonun büyüme üzerine uzun dönemde negatif etki yaratacağı sebebiyle de merkez bankasının bağımsızlı̆̆ disiplini artırıp enflasyonu düşürdüğü gibi ekonomik büyüme üzerine pozitif etki yapmaktadır. Merkez 
bankası bağımsızlığının uzun dönemde enflasyonun düşük olması dışsallığından dolayı büyümeyi artırabildiği, olumsuz dışsallığın olması durumunda büyümeyi negatif etkilediği ortaya çıkmıştır.

Arslan (2003) çalışmasına göre ise merkez bankasının bağımsızlığı enflasyon, ekonomik büyüme, bütçe açıkları gibi birçok makroekonomik değişkenle ilişkisi Avrupa Birliği ülkelerinde 1. Grup, 2. Grup ve 3. Grup ülkeler kapsamında incelenmiştir. 1. Grup ülkeler Avrupa Birliği'nin eski üyelerinden oluşmakta ve bu ülkeler için merkez bankasının bağımsızlı̆ğ, enflasyon ve ekonomik büyüme ilişkisi anlamlı bulunamamıştır. Birliğe üye ülkelerin artması ile merkez bankasının bağımsızlığı enflasyon ilişkisi anlamlı hale gelmiştir. Daha önceki çalışmalarda ortaya konulduğu gibi üye sayısının artması ile birlik içerisinde yapısal değişikliklerin meydana geldiği, merkez bankasının bağımsızlığı enflasyonu düşürücü etki yapabildiği gibi, bu etki uzun dönemde büyüme üzerinde olumlu olabileceği saptanmıştır (Arslan, 2003: 49).

\subsection{Merkez Bankasının Bağımsızlığı ve Enflasyon}

Toplum için enflasyonun düşük düzeyde tutulabilmesi, arzulanan ve olması gereken bir olgu olarak kabul edilir. Düşük enflasyonun yaratacağı başlıca yarar, ekonomik riski azaltabilmesidir. Böyle bir durumda, toplumda yerleşik enflasyon beklentileri kırılacağı için, ekonomik risk sorunu da ortadan kalkacaktır. Enflasyonun düşük düzeyde gerçekleşmesi, belirsizlikleri de azaltır. Bu nedenle, düşük enflasyon, emek ve sermaye arasındaki ilişkilerin daha iyi planlanmasına ve daha sağlıklı sözleşmelerin yapılmasına yardımcı olur (Oktar, 1996: 145). Bu doğrultuda enflasyon hedeflemesi, ileriki bir ya da daha fazla yıla ilişkin (farklı yıllara ait) enflasyon aralığı için geçerlidir.

İktisat politikasında, enflasyon hedeflemesinin bir ülkede başarı ile uygulanabilmesi için para politikasının birincil amacının fiyat istikrarı olması, merkez bankasının para politikasını belirlemede ve uygulamada tam bağımsızlığa sahip olması, enflasyon hedeflemesinin uygulanacağı ülkede gelişmiş mali piyasaların olması gibi koşullarının bulunması şart koşulmaktadır. Bunlar çerçevesinde enflasyon hedeflemesi rejimini benimseyecek ülkede para otoritesinin şeffaflık, hesap verebilirlik, güvenirlik, esneklik gibi özellikleri benimsemesi istenmektedir.

Merkez bankası parasal hedefini belirleme özgürlüğüne sahip olmalıdır. Ancak bu durumda asıl hedeflerine ulaşma imkânına sahip olur. Bir merkez bankasına sahip olmanın amacı, para politikasını en iyi uygulamak üzere kapasite ve sorumluluğu merkezileştirmektedir.

Merkez bankasının bağımsız olması, stratejinin başarısı açısından oldukça önem taşımaktadır. Bağımsızlıktan kastedilen, fiyat istikrarını sağlamada, uygulayacağı para politikası rejimini ve kullanacağı parasal araçları kendi kararı ile seçmesi ve uygulamasıdır. Diğer yandan mali ve idari açıdan özerkliğe sahip olması ve yasal görevlendirme yoluyla fiyat istikrarını sağlamda tek sorumlu otorite haline gelmesi de merkez bankasının bağımsızlığı açısından önem taşımaktadır.

Gelişmiş ve gelişmekte olan ülkeler arasında yasal bağımsızlık açısından büyük bir farklılığın olmadığı, bazı gelişmekte olan ülkelerin yasal bağımsızlığının gelişmiş ülkelerden fazla olmasına rağmen, enflasyon oranlarının yüksek olduğu dikkati çekmektedir. Yasal bağımsızlık gelişmiş ülkelerde fiyat istikrarına katkı yaparken, gelişmekte olan ülkelerde etkisi sınırlı olmaktadır. Gelişmiş ülkelerde yasal-kurumsal yapının, kurumsal tarihin ve geçmişin zenginliği başarıyı getirmektedir. Uzakdoğu ülkelerinde yasal bağımsızlık zayıf olduğu halde enflasyon oranının düşük olduğu gözlenmektedir (Cukierman ve diğerleri, 1992:362). Gelişmiş ülkelerde enflasyon ile merkez bankas1 başkanının görevden alınması arasında negatif bir ilişki, gelişmekte olan ülkelerde güçlü bir ilişki bulunmuştur. Gelişmekte olan ülkelerde enflasyonun merkez bankası politikalarından etkilenmesinin pozitif olduğu ve para otoritesinin şeffaflığının enflasyonu düşürebildiği sonucuna varılmıştır (Cukierman, 1994: 1440).

Pek çok merkez bankası para politikasının şeffaf olması konusuna büyük bir önem vermiştir. Merkez bankasının amacındaki netlik ve bu amaca nasıl ulaşılacağı konusundaki şeffaflık, belirsizliği ortadan kaldırarak ekonomik birimlerin gelecekle ilgili doğru kararlar almasını kolaylaştırmaktadır. Enflasyon düzeyini belirleyen önemli faktörlerden biri olan enflasyonist beklentiler para politikasında şeffaflık sağlanması sonucu azaltılabilmekte ve merkez bankasının enflasyon hedefiyle uyumlu bir seviyeye getirilebilmektedir (Kansu, 2007). 
Para politikasının nominal gayri safi yurtiçi hasıla (GSYIH) yerine enflasyonu hedeflemesinin nedeni enflasyonun parasal bir olgu olmasıdır. Kısa dönemde, para politikası hasılayı ve enflasyonu etkiler, asıl hedef uzun dönem hedeflerdir.

Enflasyon performansı nominal gelir performansından daha kolay gösterilebilir. Enflasyon hedeflemesi, talep şoklarına doğru para politikası ile karşılık verir. Para politikası sıkılaştıılmalıdır. Çünkü şoklar hasıla ve enflasyonu yükseltir. Enflasyon hedeflemesi, Yeni Zelanda'da diş ticaret hadleri şoklarına uyumlaştırılmıştır. Birçok ülkede, enflasyon hedeflemesi, dolaylı vergilerin etkilerini indirgemek üzere çeşitli yollara başvurmaktadır. Enflasyon hedeflemesi, gelir hedefine tercih edilmelidir. Çünkü arz şoklarına uyumludur (Fischer, 1995).

Alesina ve Summers (1993), merkez bankasının bağımsızlı̆̆ı ile birleşmiş parasal disiplinin enflasyon düzeyini ve değişkenliğin azaltmakla birlikte, reel makroekonomik performans üzerinde ciddi fayda ya da maliyetler yaratmadığını ortaya koymaktadır. Bu sonuç, aynı zamanda, paranın yansızlığını öne süren kuramlara da destek olmaktadır.

Şekil 2'de, TCMB yasal bağımsızlık oranı ve enflasyon ilişkisi 1980- 2010 yılları arasında gösterilmiştir. Buna göre, yasal bağımsızlık düzeyinin (MBB) yüksek olduğu yıllarda enflasyon oranlarının düşük olduğu, tersine düşük bağımsızlık yıllarında ise enflasyon oranı nispeten yüksek görünmektedir.

\section{Şekil 2: TCMB Yasal Bağımsızlık Düzeyi ve Enflasyon Oranları (1980 - 2009)}

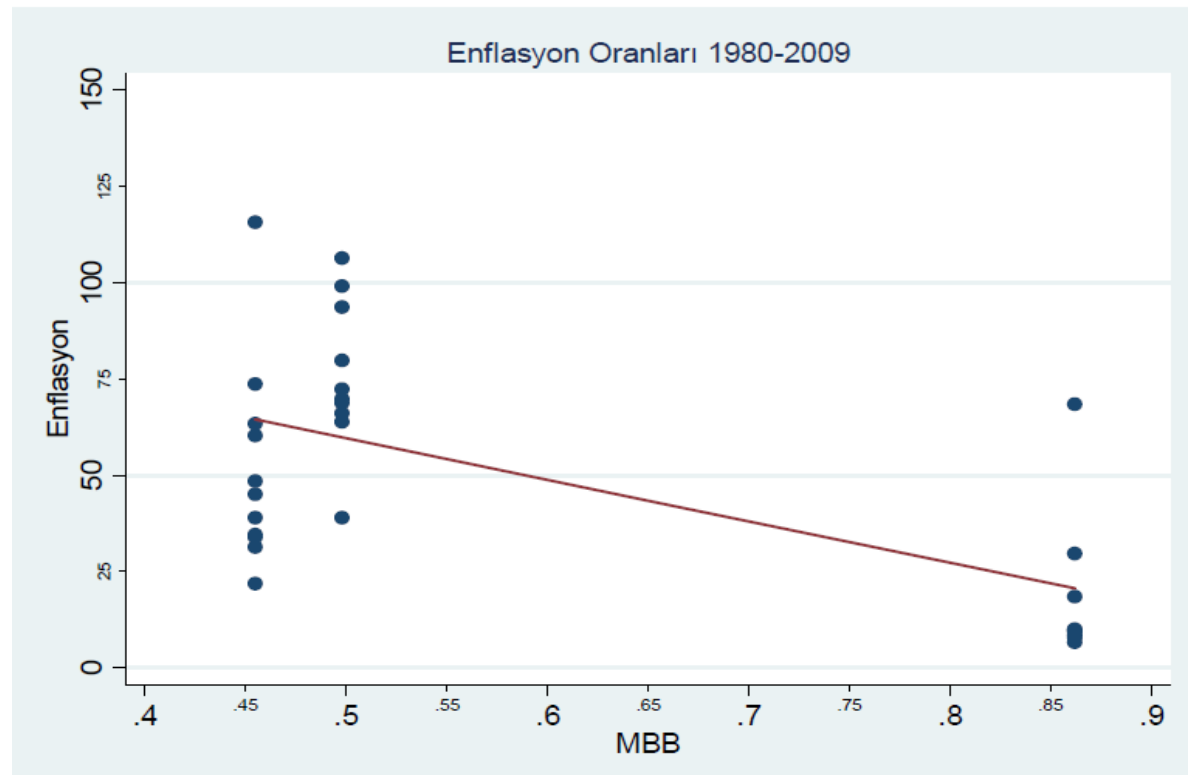

Kaynak: Demirgil, 2011.

Türkiye'de Merkez Bankası'nın yasal bağımsızlığı ve enflasyon oranlarını ilişkilendiren yukarıdaki grafiğe bakıldığında, 1980 sonrası yasal bağımsızlığın yüksek olduğu dönemlerde enflasyon oranlarının düşük olduğu belirtilmektedir. Buna göre, TCMB bağımsızlık kriterlerinden yasal bağımsızlık kriterini enflasyo hedeflemesi stratejisine uyumlu bir şekilde sağlayabilmiştir

\subsection{Merkez Bankası Bağımsızlığı ve Ekonomik Büyüme}

Merkez bankası bağımsızlığı ile ekonomik büyüme arasındaki korelasyon merkez bankası bağımsızlığı ile enflasyon arasındaki korelasyon kadar yüksek çıkmamaktadır. Alesina/Summers (1993) tarafından 1958-1988 dönemini kapsayan çalışmada bağımsızlık-büyüme ilişkisi zayıf bulunmuştur. Bağımsızlık indeksinin yüksek olduğu İsveç'te büyüme oranı düşük, Almanya'da yüksek, İtalya ve İspanya gibi merkez bankasının siyasi otoriteye büyük oranda bağlı olduğu ülkelerde yüksek bulunmuştur. Gelişmiş ülkelerde merkez bankası bağımsızlığı ile büyüme arasında ilişki olmadığı, 
gelişmekte olan ülkelerde büyümeyi belirleyen kriterlerin kontrolünden sonra (para politikası dışındaki araçların büyümeye hedeflenmesi) merkez bankası bağımsızlığının pozitif etki yaptığı, merkez bankası bağımsızlığının yatırımlar ve büyümeyi olumlu etkilediği, gelişmekte olan ülkelerde düşük bağımsızlığın düşük yatırımla ve büyümeyle birleştiği sonucuna varılmıştır (Cukierman, 1994:1440).

Merkez bankasına bağımsızlık kazandırılmasının sadece enflasyon üzerinde değil, aynı zamanda ekonominin reel büyümesi üzerinde de etkisinin olduğu genel olarak kabul edilmektedir. Ancak merkez bankasının bağımsızlığı ile yüksek ve istikrarlı bir büyüme arasında bir ilişkinin varlığını öne sürenler kadar, bu görüşü paylaşmayıp karşısında olanların sayısı da oldukça fazladır. Merkez bankasının bağımsızlığından yana olanlara göre, merkez bankasının siyasi otoritenin müdahalelerinden izole olması ve para politikasının politik konjonktürden kurtarılması, üretimde olası dalgalanmaların etkisini ve şiddetini azaltacaktır. Yine, yüksek ve değişken enflasyonun neden olduğu tahribatların ve belirsizliklerin ortadan kaldırılması, yüksek büyüme artışlarına yol açacaktır (Balls, 1991:3).

Siyasi nüfuza ve baskılara açık olmayan bir merkez bankasının reel değişkenler üzerinde etkisi büyük olmaktadır. Bağımsız bir merkez bankası, reel ekonomik performansı özellikle şu nedenle artırabilir. Siyasi baskıların dışında kalabilmeyi başarabilmiş bir merkez bankası, ekonomik istikrarı devam ettirmede ve reel faiz hadlerinde risk primini düşürmek için daha öngörülü bir davranış içinde olabilecektir. Daha özgül bir deyişle, bağımsız bir merkez bankası, ekonomiyi, para politikasının seçim öncesi manipülasyonunu önleyerek siyasi çevrimlerden izole edebilir (Oktar, 1996: 153).

Doğru ( 2013) çalışmasına göre, Türkiye'de merkez bankası bağımsızlığının çıktı açığı üzerine pozitif yönde oldukça önemli bir etkisi vardır. Yani yasal bağımsızlık arttıkça reel büyüme incelenen dönem boyunca artmıştır. Para politikalarının yönetici konumundaki merkez bankalarının (MB) reel büyüme üzerindeki etkileri tartışmasızdır. Hem fiyatlarda istikrar hem de büyümede istikrar sağlanması için yasal ve siyasal anlamda bağımsız bir MB günümüzde olmazsa olmazlardandır. Ancak yine de ülkelerin yönetim şekillerine, uyguladıkları iktisadi rejimin durumuna, demokratik olup olmadıkları ve gelişmiş ya da gelişmekte olan bir ülke olmasına göre reel büyüme ile merkez bankası bağımsızlığı arasında farklı sonuçlar söz konusudur. Örneğin İsviçre ya da Japonya merkez bankası çok bağımsız olmalarına rağmen, bu ülkelerin büyüme oranları oldukça düşüktür. Fakat merkez bankaları hükümete bağımlı olan İsveç ve Norveç’te de büyüme oranları yavaştır. Şimdiye kadar yapılan çalışmalarda merkez bankası bağımsızlığının gelişmekte olan ve gelişmiş ülkeler için farklı sonuçlar vermesi yüzünden MB bağımsızlı̆ğ ile büyüme arasında her ülke için geçerli olacak bir kural ortaya çıkamamıştır.

Birçok araştırma, merkez bankasının bağımsızlığı ile düşük enflasyon arasında yüksek bir korelasyon saptamalarına karşın, merkez bankasının bağımsızlığı ile ekonomik büyüme arasında ise, bu denli bir korelasyonun varlığı ortaya çıkmamıştır (Grilli, Masciandaro, Tabellini, 1991; Alesina ve Summers, 1993; Cukierman, 1994). Bağımsızlık ile ekonomik büyüme arasında farklı sonuçlara ulaşılmıştır.

Örneğin Alesina ve Summers(1993) çalışmasında, 1955- 1988 yılları arasını kapsayan araştırmalarında söz konusu ilişki zayıf bulunmuştur. Bu araştırmaya göre, İsviçre yüksek bir bağımsızlık derecesine sahip olmasına karşın, araştırmaya konu olan yıllar arasında oldukça bağımsız merkez bankalarına sahip olan Almanya ve İsviçre'de ekonomik performans nispeten yüksek düzeyde gerçekleşmiştir. Merkez bankasının bağımsızlığı ile ekonomik büyüme arasındaki ilişkinin zayıflığını ortaya koyan en belirgin örnekler İspanya ve İtalya'dır.

Şekil 3'e bakıldığında ise, TCMB yasal bağımsızlık düzeyleri ve ekonomik büyüme oranları yine 1980-2009 yılları arasını göstermektedir. Bu bağlamda da yasal bağımsızlık düzeyi ekonomik büyüme oranı ile belirtilen dönem için doğrusal olarak ilişkilidir denebilir. 
Şekil 4: TCMB Yasal Bağımsızlık Oranı ve Ekonomik Büyüme (1980 - 2009)

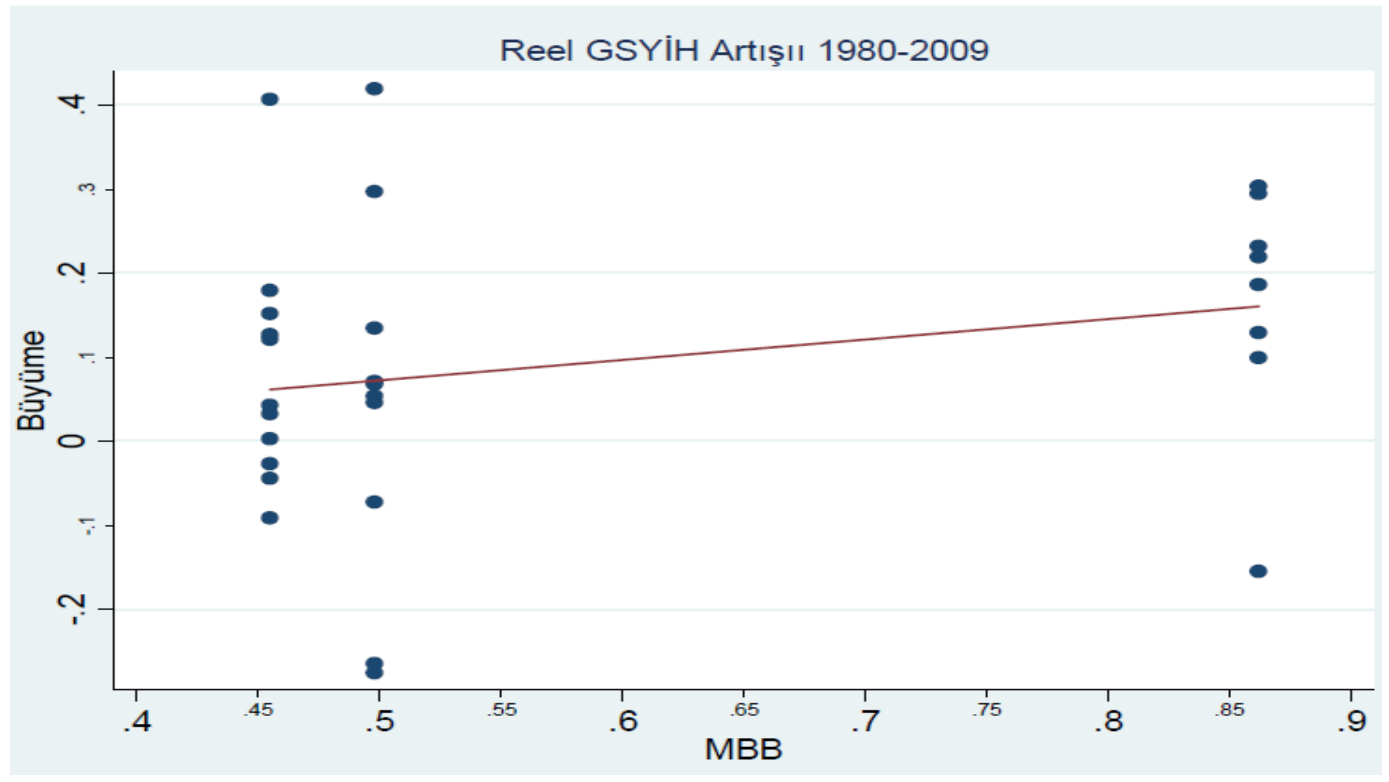

Kaynak: Demirgil, 2011.

Merkez bankası yöneticilerinin devir hızı ile ilgili sonuçlar çeşitlidir. Devir hızı ekonomik büyüme ile ters orantılı bir ilişki gösterir. Çünkü devir sayısı arttıkça, devir hızı yükselir, merkez bankası bağımsızlığı ve ekonomik büyüme ilişkisinin pozitif olduğunu gösterir. Genel sonuçlar gösteriyor ki, merkez bankası bağımsızlı̆̆ uzun dönemde ekonomik büyüme üzerinde önemli etkiye sahiptir (Samimi, A.J.,Rajabi, S., Shahir, S.A., 2010)

\section{SONUÇ}

Merkez bankası bağımsızlığı ve makroekonomik performans arasındaki ilişki, 1960'lı yıllardan itibaren çeşitli analizlerle ortaya konulmuştur. Gelişmiş ekonomilerde merkez bankası bağımsızlık düzeyinin yüksek olduğu ve bu durumun makroekonomik göstergeleri olumlu etkilediği gözlenmiştir.

Siyasi otoriteler, siyasetin doğasından kaynaklanan nedenlerle kısa vadeli bakış açısına sahip baskı gruplarının etkisi altında kalabilmekte ve özellikle seçim dönemlerinde daha kısa vadeli düşünmeye yatkın olabilmektedir. $\mathrm{Bu}$ noktada enflasyonu kontrol etmek, fiyat istikrarına, sürdürülebilir büyümeye ulaşmak için merkez bankaları, toplum tarafından daha uzun vadeyi planlayabilmeleri için siyasi otoriteden bağımsız olarak görevlendirilirler (Erçel, 2005, www.tcmb.gov.tr).

Merkez bankası bağımsızlığında oldukça önemli bir unsur olarak görülen ve merkez bankası başkanının politik baskılardan korunması amacıyla getirilen görev süresi ve görevden alınmaya ilişkin yasal güvence sağlanmıştır. Ancak karar almada politik baskıların tamamen ortadan kaldırıldığını düşünmek pek mümkün değildir. T. C. Merkez Bankası ile ilgili olarak, hazinenin ağırlıklı olarak söz sahibi olma imkânı bulduğu Genel Kurulca ${ }^{3}$ seçilen Banka Meclisi ${ }^{4}$ üyelerinin karar almada tarafsızlıklarını ne derece koruyacakları önem taşımaktadır. Bununla birlikte, T.C. Merkez Bankası'nın ekonomik bağımsızlığı yasal olarak korunmuştur.

\footnotetext{
${ }^{3}$ Banka'nın pay sahipleri defterinde adı yazılı bulunan hissedarlar tarafından oluşmaktadır. Banka Kanunu’nda tanımlandığı üzere, Banka hisselerinin en az yüzde 51'i Hazine'ye ait olup, kalan kısmı milli bankalar, yabancı bankalar ve Türk ticaret müesseseleri ve Türk vatandaşlı̆ına haiz gerçek ve tüzel kişilerce sahip olunmuştur.

${ }^{4}$ Başkan ile Genel Kurulca seçilen altı kişiden oluşmaktadır. Görev süresi üç yıldır.
} 
Para ve kredi politikasının T.C. Merkez Bankası ve Hazine ile birlikte yürütülmesi, Türkiye'nin ekonomik yapısında kronik bir sorun haline gelen kamu kesimi açılarının yeterli kaynak bulunamaması dolayısıyla merkez bankasının kamu sektörünün finansman ihtiyacını karşılaması, T.C. Merkez Bankası tarafindan bağımsız olarak fiyat istikrarının sağlanmasına engel teşkil etmektedir. Oysaki merkez bankalarının temel hedefi olan fiyat istikrarının sağlanması bağımsızlığın da ön koşulu olmaktadır. Yasal olarak T.C. Merkez Bankası fiyat istikrarını sağlamakla yükümlü kılınmıştır. Ancak Türkiye gibi bütçe ve kamu kesimi açı̆̆ının çok büyük olduğu ve Merkez Bankasının kamu kesimini finanse eder durumda olduğu bir ülkede yapısal bu problemin aşılması oldukça zor görünmektedir. Para politikasının yürütülmesinde tek yetkili kurum olması halinde T.C. Merkez Bankasının esas hedefinin fiyat istikrarını sağlamak olması güç olmayacaktır.

Türkiye'de de bağımsızlık endeksi ve makroekonomik performans arasındaki ilişkiden bahseden teorik çalışmalar bulunmaktadır. Bununla beraber, merkez bankası bağımsızlığını ölçen ve söz konusu ilişkinin yönünü belirlemeye yönelik araştırmalar da vardır. Ayrıca, merkez bankası bağımsızlık düzeyi ile makroekonomik göstergeler arasındaki ilişki kantitatif yöntemlerle ortaya konmaktadır.

Sonuç olarak, ekonomik ve politik çerçevede bağımsız bir merkez bankasına sahip olunması bir ülke ekonomisinde öncelikle fiyat istikrarının sağlanıp korunmasında, yani enflasyon oranının kontrollü bir trend sergilemesinde, ayrıca da ekonomik büyüme, çıktı açı̆̆g, makroekonomik performans gibi kriterler üzerinde önemli bir etkiye sahiptir. Bağımsızlık, yönetişim, şeffaflık ve hesap verebilirlik gibi konularla bağdaştırılmıştır. Bağımsızlık derecesi, iyi yönetişim, şeffaflık ve hesap verebilirlik konularında etkin bir merkez bankasında daha yüksek düzeyde, enflasyon oranı ile negatif, ekonomik büyüme ile pozitif ilişkilidir.

\section{KAYNAKÇA}

AFŞAR, B. (2006), "Seçilmiş Dünya Merkez Bankalarına Örnekler (ABD Merkez Bankası-Almanya Merkez Bankası-İngiltere Merkez Bankası İtalya Merkez Bankası-Fransa Merkez Bankas1Japonya Merkez Bankası Hollanda Merkez Bankası)", http://www.kto.org.tr/d/file/ulkemerkezbank rapor.pdf (08.03.2014).

AHSAN, A., Skully, M., ve Wickramanayake, J., (2006), "Determinants of Central Bank Independence and Governance: Problems and Policy Implications", JOAAG, Vol.1, No.1, pp.47-61.

ALESINA, A. (1989), "Politics and Business Cycles In Industrial Democracies", Economic Policy, V.89, Say1:8, pp. 55-98.

ALESINA, A. ve Summers, L. H., (1993), "Central Bank Independence and Macro Economic Performance: Some Comparative Evidence", Journal of Money, Credit and Banking, Vol 25(2), pp. 151-162.

AMTENBRICK, F., (2004), "The Three Pillars of Central Bank Governance, Towards a Model Central Bank Law or a Code of Good Governance?", IMF LEG Workshop on Central Banking, and IMF LEG and IMF Institute Seminar on Current Developments In Monetary and Financial Law, 2004. 
ARSLAN, Ö. (2003) “Avrupa Birliğì’ni Oluşturan Ülkelerde Merkez Bankası Bağımsızlığı, Enflasyon ve Diğer Makro Ekonomik Büyüklükler Arasındaki İlişkiler: 1980- 2001",’Uzmanlık Yeterlik Tezi, TCMB, Piyasalar Genel Müdürlüğü, Ankara.

BALLS, E., (1991), “A Modest Case for an Independent Central Bank", Deutsche Bundesbank/ Auszüge Aus Presseartikeln, No:82.

BORRERO M., A. (2001)“On the Long and Short of Central Bank Independence, Policy Coordination and Economic Performance”, IMF Working Paper.(WP/01/09).

CASTELlO, M. - Branco ve Mark Swisburne, (1992), "Central Bank Independence", Finance\& Development, Vol:29, No:1, pp.19-21, Çev. Hüseyin Şen, Banka ve Ekonomik Yorumlar Dergisi, Y11:36, Şubat 1999.

CUKIERMAN, A. (1994), "Central Bank Independence and Monetary Control", The Economic Journal(November), pp.1437- 1448 .

CUKIERMAN, A., S. B. Webb ve B. Neyapti, (1992), "Measuring the Independence of Central Bank and its Effect on Policy Outcomes", World Bank Economic Review, Vol.6(3), pp. 353-398.

CUKIERMAN, (1995), A.Central Bank Strategy, Credibility, and Independence: Theory and Evidence, Massaschusetts: The MIT Press.

DEMIRGIL, H. (2011), "Merkez Bankası Bağımsızlığı ve Makroekonomik Performans: TCMB Örneği”, Sosyoekonomi, 2011-2, s. 113-133.

DİLEYİCİ, D. ve Özkırak, Ö. (2000), "Yeni Yüzy1lda Mali ve Parasal Politikalarda Yeniden Yapılanma", Dokuz Eylül Üniversitesi Sosyal Bilimler Enstitüsü Dergisi, C.2, S.2, s.80-109.

DOĞRU, B., (2013), "Effect Of Central Bank Independence To Output Gap: Case Of Turkey", Dumlupınar Sosyal Bilimler Dergisi, Sayı:35, pp. 25-40.

ERÇEL, G., (2005), Merkez Bankası'nın Bağımsızlı̆̆ı, 2005, TCMB.

FISHER, S.,(1995), “Central Bank Independence Revised”, American Economic Review, Vol. 85, No:2, pp. 201- 206.

GRILLI, V., D. Masciandaro, ve G. Tabellini, (1991), "Political and Monetary Institutions and Public Financial Policies in the Industrial Countries”, Economic Policy, Vol. 6(2), pp. 341-392.

GRILLI,V. Masciandaro D ve Tabellini G., (1994), "Political and Monetary Institutions and Public Financial Policies in Industrial Countries". In T. Persson ve G. Tabellini (ed), Monetary and FiscalPolicy, Second Edition, Massachusetts: The MIT Press, ,s. 205-207. 
HENNING, C. R.(1994), "Currencies and Politics in the United States, Germany and Japan", Washington, D.C: Institute for International Economics.

KANSU, A. (2007), "Para Politikasında Şeffaflık ve Enflasyonist Beklentilerin Yönlendirilmesi”, Doğuş Üniversitesi Dergisi, Y11:2007, Cilt:8, Sayı:1, s. 59-71.

KARAKUŞ, G. (2010), "5018 Sayılı Kanun İle Yönetişim İlke ve Esasları Çerçevesinde Kamu Hizmetlerinin Sunumu", Mesleki Yeterlilik Tezi, T.C. Maliye Bakanlığı, Strateji Geliştirme Başkanlı̆̆ 1 , Ankara.

KILIÇ, M.,(2002), “T.C. Merkez Bankası Bağımsızlığı ve Enflasyon”, BBP Sanal Bülten, İstanbul.

KOOJ J., W. ve De Haan J. (2000) "Does Central Bank Independence Really Matter? New Evidence for Developing Countries Using A New Indicator.", Journal of Banking and Finance, v. 24 iss.4, pp. 643-664.

LYBEK, T. (2004), “ Central Bank Autonomy, Accountability, and Governance: Conceptual Framework", Seminar Paper LEG Seminar, 2004.

OKTAR, S. (1996), Merkez Bankalarının Bağımsızlığı, Bilim Teknik Yayınevi, Eskişehir.

SAMIMI, A.J.,Rajabi, S., Shahir, S.A., (2010), "The Impact of CBI On Economic Growth: A CrossSection Analysis", Australian Journal of Basic and Applied Sciences, 4(10), pp. 4823-4831.

STURM, J- E. ve De Haan J. (2001) "Inflation in Developing Countries: Does Central Bank Independence Matter? New Evidence Based on A New Data Set", Ifo Studien, v.47, iss.4, pp. 389-403.

TCMB, (2012), Türkiye Cumhuriyet Merkez Bankası ve Bağımsızlık, www. tcmb.gov.tr

TCMB, (2013), http://www.tcmb.gov.tr/yeni/evds/yayin/kitaplar/Bagimsizlik2013.pdf. (11.03.2014).

The World Bank (1994); Governance: The World Bank's Experience. Washington, D.C: World Bank.

The World Bank (1992), Governance and Development, Washington DC.

ZINGALES L. (1997), “Corporate Governance”, Workingpaper 6309, National Bureau of Economic Research. 